\title{
Self- help Groups and Women's Empowerment: Evidence from Gaoua in Burkina Faso
}

\author{
Ollo Dah ${ }^{1}$ Moussa Sigue ${ }^{1}$ Boureima Zalle ${ }^{2}$ \\ ${ }^{1}$ Thomas Sankara University, department of economics \\ ${ }^{2}$ Freedom university of Burkina \\ Corresponding author: Ollo Dah: ollodah41@yahoo.fr
}

Received 03 August 2020;

Accepted 11 August 2020;

Published 19 August 2020;

\begin{abstract}
Self- help groups are increasingly becoming platforms used by development organizations to induce behavioral change and especially to target women's empowerment, but little is known about the effectiveness of such policies. This paper examines the contribution of Self- help groups to women's empowerment in Burkina Faso, focusing on the case of the township of Gaoua through data collection from a reasoned choice sample of beneficiaries. The results show that membership of women in these groups enables them to increase their purchasing power, which in turn enables them to participate in the primary needs of their households and thus improve their empowerment. Therefore, it is suggested to the development actors intervening in the township of Gaoua to put together their efforts to cover all the villages of the Self- help groups in order to enable a large number of women to benefit from the spin-offs of these projects.
\end{abstract}

Keywords: Self-help groups, Savings, Credit, women's empowerment, Gaoua, Burkina Faso

\section{Introduction}

Women's empowerment takes a central place in the development programs of developing countries and is increasingly the subject of a fascinating debate for the various development actors (government, NGOs, researchers, etc.). In these countries, there is a blatant reality of the imbalance between men and women. Indeed, $70 \%$ of the people living with less of one dollar a day are women. Moreover, in developing countries, women are mainly active in the unruly domestic economy (UN, 2012).

In Burkina Faso, the situation of women is not good enough. It has a literacy rate of $26 \%$ for women compared to $45 \%$ for men and an unemployment rate of $20 \%$ for women compared to $8 \%$ for men (Information Agency of Burkina, 2017). Moreover, access and control of financial resources is a challenge for the majority of the population, especially women. Banking infrastructure is not sufficiently provided. The ratio of bank branches and ATMs to the size of the population places Burkina Faso as the last but one of the West Africa Economic and Monetary Union (WAEMU) States. In 2016, Burkina Faso had 281 bank branches and 376 ATMs with only an $18 \%$ bank penetration rate. Microfinance institutions (MFIs) are slightly more accessible than banks, although the difference is not very significant. On average, it takes 30 minutes to get to the nearest MFI branch (Jefferis and Abdulai, 2017).

There are considerable differences in the use of financial products according to gender. Statistics show that women's access to financial resources provided by state funding funds is low compared to men. In 2017, for example, the amount of credit granted to women by the government of Burkina Faso amounts to 1,0167 billion compared to 2,0626 billion for men. Thus, women were only able to pocket $33 \%$ of the manna to be shared compared to $67 \%$ for men. In 2018 , the situation has clearly improved to reach $38 \%$ (545 million) of the total amount against $62 \%$ (902, 9 million) for men. Lack of access to basic financial services limits women's ability to invest in income-generating activities to enhance their economic empowerment (Directorate-General for Studies and Sectorial Statistics, 2019).

The socio-economic situation of women in the township of Gaoua is in line with that of the country's national situation. With a view to improving the status of women, the government of Burkina Faso, with the support of its technical and financial partners, has been making enormous efforts for years through projects and programs. These include the economic empowerment program for youth and women initiated by the Burkinabe government in 2017, the adoption of the national strategy for the promotion of women entrepreneurship (NSWEP) in June 2015. For the implementation of these projects, access to financial services is an important lever. It is from this perspective that NGOs and associations are carrying out actions in the field of community microfinance in order to enable those excluded from traditional financial institutions to access financial services (savings, credit, insurance) under fairly flexible conditions where the guarantee is mainly a solidarity guarantee. These actions are aimed at the involvement and active participation of women in socio-economic development. CARE, an international NGO, launched its first official savings group program in Niger in 1991, and several reputed NGOs, including Catholic Relief Services, Plan International, Oxfam, the Aga Khan Foundation, World Vision and Pact, have since introduced savings groups promotion programs throughout the African continent (Odell, 2012; Odell \& Rippey, 2011).

For the township of Gaoua, the NGO Plan International has been initiating self- help groups since 2010 with a view to 
facilitating access to financial services for its members. These are groups of 20 to 30 women who save together and make small loans from these savings. The activities of these groups operate in cycles of about one year, at the end of which the accumulated savings and the profits from loans are distributed among the members in proportion to the amount they have saved. The aim of this work is to analyze the contribution of these savings and loan groups to the standard of living of the beneficiaries that are mainly women, by assessing their empowerment both socially and economically.

The theoretical corpus of this research is based on the theory of change. It is a method that explains how a given intervention or set of interventions is expected to lead to a specific development change, through an analysis of causality based on existing evidence (Rogers, 2014). The policy logic behind the activities of self- help groups is that the use of financial services should have a positive impact on people's income. In theory, financial services could bring benefits to the poor by changing their financial behavior by enabling them to use financial services to access new sources of income or improve existing sources, to save money that they would otherwise spend or waste, to invest in an income-generating activity, to smooth consumption or to cope with shocks. More specifically, credit can be used to start or expand a business that then makes a profit, or to access a new (other) income-earning opportunity (Duvendack and Mader, 2019).

Behavioral economists argue that financial services, particularly those that contain special modalities to affect user behavior, lead to a variety of potentially desirable cognitive abilities and behavioural changes. The World Bank has endorsed this idea in recent years. In theory, changes in behaviour and cognitive abilities could result from several factors. Indeed, changes in financial knowledge and capability could come directly from teaching in financial education programs that are sometimes linked to the provision of financial services or from experience gained over time in using financial services. Financial products can also change users' money-use patterns over time, for example, leading to higher propensities to save, more investment in income-generating activities or less spending on particular goods such as "temptation goods" (Banerjee et al. 2015).

Several empirical analyses have been conducted and have highlighted the positive effects of access to credit on women's well-being (Khandker, 2005; Mahtab, 2007; Haque and Itohara, 2009; Nawaz et al., 2012; Voica, 2017). These authors conclude that credit empowers women beneficiaries by improving their incomes. Most of these studies have focused on the effects of conventional MFIs on beneficiaries by focusing only on the credit part of the programs in microfinance. However, community-based microfinance, consisting mainly of self- help groups, has a different mode of operation from traditional MFIs. Some empirical studies on the effects of self- help groups have been conducted in Asian countries (Rosenberg, 2011; Nessa et al., 2012; Mukherjee and Kundu, 2012; De Hoop et al., 2014; Banerjee et al., 2015); but in Africa empirical studies on this issue are very limited (Mercer, 2002; Hargreaves et al., 2009). In addition, very few studies have followed a qualitative approach in order to take into account social aspects such as health, education and social networks. In a context where this mode of financing is emerging in Burkina Faso to cover the financial needs of rural and semi-urban populations with women as a target, empirical analysis of these aspects in relation to women's socio-economic empowerment is important.

Therefore, this paper questions the contribution of self- help groups to the improvement of the socio-economic conditions of the beneficiaries. Therefore, the general objective of this paper is to analyze the contribution of self- help groups on the socio-economic empowerment of women in the township of Gaoua. Specifically, the research aims to determine the contribution of self- help groups in meeting the needs of beneficiary households, on household relations and to identify the initiatives that the advent of these groups would have enabled the beneficiaries to undertake. Thus, the work is based on the main hypothesis that participation in selfhelp group's activities empowers beneficiaries both economically and socially. Thus, it is assumed that the services provided to members of savings and credit groups enable them to contribute to household needs and thus increase their bargaining power within their households. In addition, it is assumed that self- help groups promote the implementation of income-generating activities (IGAs).

The work is structured in three sections. The first section presents the methodology and data description. The second section presents the results followed by discussion and the last section makes a conclusion followed by policy implications.

\section{Methodology and data sources}

The data used for the empirical analysis of this paper are primary data collected from September to October 2018 by the field officers under the supervision of the authors of this paper. The paper focused on women beneficiaries of savings and credit in the township of Gaoua. As a result, a questionnaire was developed and addressed to the beneficiaries.

We have chosen a reasoned choice sample, which gave all members of self- help groups a chance to be included in the sample. Thus, two hundred and ten (210) female beneficiaries were interviewed.

In addition to our target audience, heads of households are considered as the control population. Even if they are not directly concerned by the study, their information allows us to have more knowledge of the effects of savings and credit on the beneficiaries. As a result, twenty (20) heads of households were interviewed.

This research also took into account the opinion of other key persons to better appreciate the results of the beneficiaries. These key persons are those who have knowledge on our research theme, they are also people involved in development projects and programs relating to the socio-economic empowerment of women and people knowledgeable about microfinance for their experiences in the field. Table 1 provides a summary of the interviewees.

Table 1: Summary of interviewees

\begin{tabular}{|l|l|c|}
\hline $\begin{array}{l}\text { Categories of } \\
\text { interviewees }\end{array}$ & Socio status Professional & Number \\
\hline Target population & Members of self- help groups & 210 \\
\hline Control population & Heads of household & 20 \\
\hline \multirow{3}{*}{ Target people } & $\begin{array}{l}\text { In charge or promoters of } \\
\text { projects for the socio-economic } \\
\text { empowerment of women }\end{array}$ & 04 \\
\cline { 2 - 3 } & Self- help groups supervisors & 07 \\
\hline Total & & 241 \\
\hline
\end{tabular}

Source: Authors

\section{Results and discussion}

This section presents the results from the compilation of the survey data. The effects of self- help groups were analyzed both socially and economically.

\section{1- Self- help groups and social women's empowerment}


With respect to the social aspects of women's empowerment, this research builds on the variables of education, health, nutrition and wife-husband relationships within households. These variables are important indicators of women's empowerment and have been used by several authors to capture women's empowerment (Steel et al, 1998; Sherman et al, 2010; Rosenberg, 2011). This subsection relates these variables to participation in self- help groups.

Graph 1 presents the results in terms of education. The field survey deciphered ninety-one (81) children attending school before the advent of self- help groups for all the two hundred and ninety (210) women interviewed. The distribution by cycle shows forty (40) in primary school, thirty (30) in post-primary school, ten (10) in secondary school and one (01) in higher education. With the advent of the project, the income earned from savings and credit distributed among the members of the groups made it possible to continue the schooling of 164 children, including eighty-seven (87) children in primary school, forty-two (42) in post-primary, thirty (30) in secondary and five (05) in higher education. The resources from savings and credit have thus made it possible to improve the school enrolment and retention rate. At this level, we note the testimony of women members of self- help groups, who affirm that: "thanks to savings and credit, we are now able to participate in the school fees of children". Again, a member of the supervisory team of the self- help groups said: "At the beginning of the project, we saw that there were children participating in meetings with their mothers, when we asked why they were there, the mothers replied that they had sent them away from school because of lack of financial means. But today, most of these women are able to pay for school fees, supplies, clothing and health care for their children.

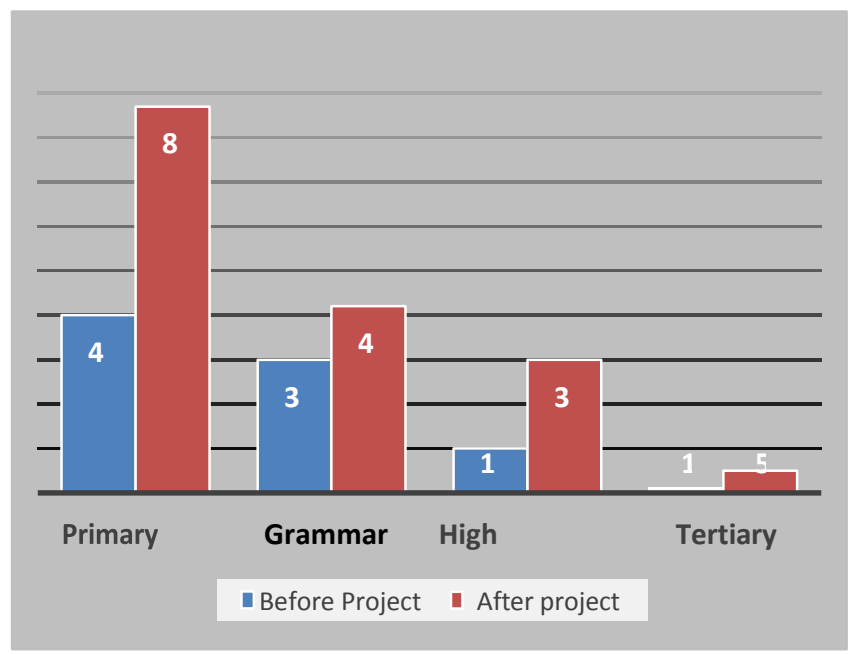

Source: Authors based on compilation of survey data.

\section{Graph1: Induced change in the level of schooling of children}

On the health front, the income earned through savings and credit is used to cover the health expenses of children and family members, in particular through attendance at health centers. On this point, it appears from our surveys that before the existence of self- help groups, only $7 \%$ of the women surveyed could afford medical care. With the existence of the project, $85 \%$ are able to afford medical care. One beneficiary confided to us that "before we did not go to the health centers because we were afraid we would not be able to honour the prescriptions that the doctor would prescribe us. But, since joining the self- help groups, we go there without fear". These results may be explained by the fact that facilitators, that may have promoted changes in health practices through the awareness sessions, supervise the self- help groups.
Our findings are consistent with studies of other community health interventions, such as Lassi, Haider and Bhutta (2010) and Lassi, Kuman and Bhutta (2016).

In terms of food, our field investigations reveal that only $14 \%$ of the women interviewed were able to have two (02) meals per day. Since the existence of the project, eating habits seem to improve with the project activities that have increased the purchasing power of beneficiaries who are able to vary the food. In fact, the results of the study reveal that since participating in the self-help group's activities, $65 \%$ of the families surveyed regularly eat the three (03) daily meals, namely breakfast, lunch and dinner with a food variation in the menu. This was not the case before the advent of these groups. During our interviews, one of the beneficiaries, president of a self- help group, also testified to the positive effects on the improvement of their living conditions: "Our membership in these groups is very advantageous for us and especially our children. Savings and credit have enabled us to pay for school fees, supplies, medical expenses, and clothing and to ensure a regular and balanced diet for our children, which was difficult before the project. In addition, to this day, we are able to buy meat, fish, and condiments of our choice for our sauce. We are like civil servants now, we eat well. We can only thank the NGO Plan International for setting up these groups, because if we hadn't been beneficiaries of the project we wondered what would become of us in this community".

In terms of the relationship at home, self-help group's activities consolidate the relationship between couples. The husbands of the beneficiaries of this project maintain that the women's savings and credit activities help them enormously. One head of household said: "Since our wives belong to the self- help groups, they help us with household expenses, and they don't even wait for us for certain expenses. We are proud of our wives. The women testify that their marital situation has improved. They are increasingly consulted and listened to by husbands in household decisionmaking. Hearing the testimonies of many women, savings and credit project plays a positive role in gender dynamics because for them, access to savings and credit activities allows them to acquire a certain autonomy. Our results corroborate those found by other authors who have shown that women's participation in self- help groups promotes greater control over decision-making within the household (Bhoj et al, 2013; Caro et al, 2013; Desai and Joshi, 2013; Holvoet, 2005). A preliminary conclusion is that participation in self- help groups could be particularly useful in supporting behavioural change. Authors reach similar conclusions by showing that access to financial services has positive effects on women's education, health and bargaining power within households (Pitt and Khandker, 1996; Ackerly, 1995; Hashemi et al, 1996; Sarkar, 2000).

\section{2: Self- help groups and women's economic empowerment}

It is important to note that most of the women members of selfhelp groups were without activities after the raining season, which is the propitious period for agricultural production. They therefore spend a long period of unemployment during the dry season, which negatively affects their incomes. Since joining self- help groups, there has been an improvement in the income of the beneficiaries in that they have not only saved and granted themselves credit but also carried out income-generating activities.

As shown in graph 2, creation of savings and the distribution of these savings in the form of credit have enabled women members of these groups to develop income-generating activities, which has improved their incomes. In fact, data on their monthly income show that out of the 210 women surveyed, 10 women registered 
less than 5,000 FCFA, 90 women had an income of between 5,000 and 10,000 FCFA, 80 women had an income of between 10,000 and 21,500 and 30 women had an income of between 21,500 and 31,500 FCFA.

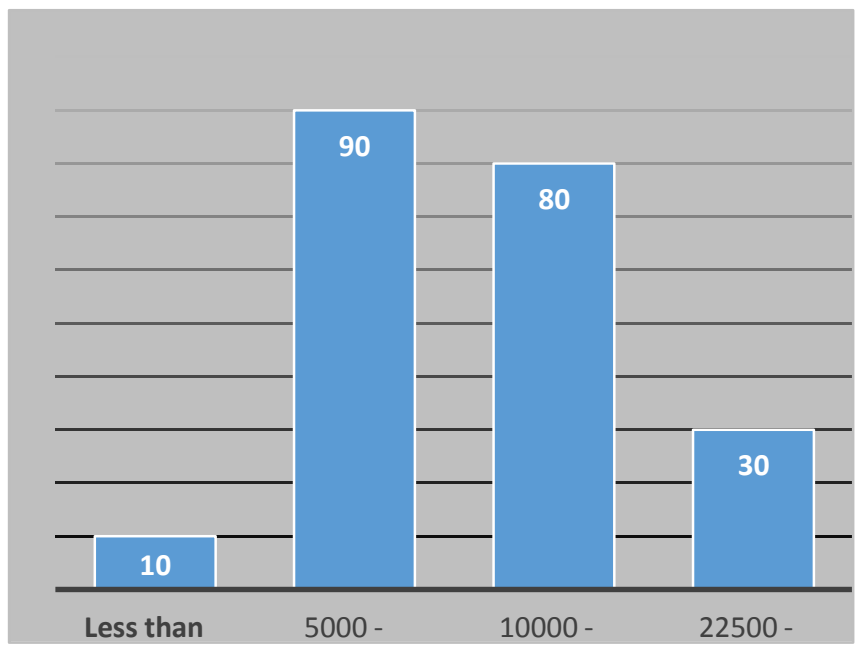

Source: Authors' compilation based on October 2018 survey data.

\section{Graph 2: Revenues recorded per month on activities}

Table 2 shows that the beneficiaries of self- help groups allocate the funds from these initiatives among several income-generating activities. In fact, $9.52 \%$ of the respondents were able to undertake, thanks to their new source of income, pig breeding; $14.29 \%$ were able to acquire small ruminants for breeding; $57.14 \%$ of them were able to engage in the field and garden trade, and the remaining $19.05 \%$ have chosen to create restaurants.

Table 2: The different IGAs carried out by the beneficiaries of self- help groups

\begin{tabular}{|l|l|l|}
\hline Types of investment & Number & Percentage \\
\hline Pigs breeding & 20 & $9.52 \%$ \\
\hline Sheep and goats breeding & 30 & $14.29 \%$ \\
\hline Trade, farm, gardening & 120 & $57.14 \%$ \\
\hline Restaurants & 40 & $19.05 \%$ \\
\hline Total & 210 & $100 \%$ \\
\hline
\end{tabular}

Source: Authors' compilation based on survey data.

The results showed that participation in self- help groups improved savings rates and access to credit, facilitating investment in income-generating activities. Studies have shown similar results by showing that group members are more proactive in implementing IGAs (Gugerty et al. 2019, Greaney et al. 2013).

\section{Conclusion and implication of development policies}

The main objective of this study was to analyze the contribution of self- help groups to the socio-economic empowerment of women in Burkina Faso with a focus on the township of Gaoua. To do so, data were collected from a sample of a reasoned choice among members of self- help groups. Key people were also interviewed for further analysis. The results obtained from the analysis of the collected data support our hypotheses.

The main hypothesis according to which participation in selfhelp groups activities makes the beneficiaries autonomous both economically and socially is verified. Indeed, the income from savings and credit has enabled the beneficiaries, mainly women, to continue the schooling of many children in primary school, post- primary school, secondary school and higher education. In addition, the income earned through savings and credit is used to cover the health and food expenses of the beneficiaries and their family members.

In addition, the knowledge and experience acquired through savings and credit have enabled the beneficiaries to develop initiatives in terms of income-generating activities in the township of Gaoua. These activities, which enable women to contribute to household expenses, help to strengthen the status of women within the household. Husbands in view of their growing economic autonomy increasingly respect them.

Overall, it appears that self- help groups have had a positive economic and social effect on the beneficiary families and hence the socio-economic empowerment of women. In view of the results of this research, we felt it necessary to make a number of recommendations that, if implemented, could improve what has been found. In view of the positive impact of self- help groups, development actors should combine their efforts to scale up these groups to cover non-beneficiary localities.

It will also be necessary to create a framework for regional consultation so that the actors involved in the promotion of women's empowerment can meet to exchange and learn from each other's experiences on the various actions being carried out in the field. This synergy of action between the various actors (State, NGOs, associations, civil society) will make it possible to better plan their budgets and reach more targets by avoiding duplication of targets and working instead in a dynamic of complementarity. Local authorities as well as territorial authorities have an important role to play in bringing these NGO initiatives to scale and in ensuring the sustainability of these groups when the implementing agencies come to the end of the project. In addition, an emphasis must be placed on women's literacy and this will improve the proper functioning of self- help through the proper maintenance of members' account books.

Despite the interesting results of this research, it could be improved by further research in the future by enlarging the sample and comparing self- help groups of the different implementing agencies to better appreciate the results.

Statement of Competing Interests: the authors have no competing interests

\section{List of abbreviations}

DGSSS : Directorate-General for Studies and Sectorial Statistics

IAB : Information Agency of Burkina Faso

IGA : Income-Generating Activities

MFI : Microfinance institutions

NSWEP : National Strategy for Women Entrepreneurship

Promotion

WAEMU: West Africa Economic and Monetary Union

\section{Conflicts of Interest}

The author(s) declare(s) that there is no conflict of interest regarding the publication of this paper.

\section{Funding Statement}

There is no funding in this research.

\section{References}


[1] Banerjee, A., Duflo, E., Glennerster, R., \& Kinnan, C. (2015). The Miracle of Microfinance? Evidence from a Randomized Evaluation. American Economic Journal: Applied Economics, 7(1), 22:53.

[2] Bhoj, S., Bardhan, D., \& Kumar, A. (2013). Determinants and implications of rural women's participation in microfinance programme: An analysis of dairy self- help groups in Uttarakhand State of India. Livestock Research for Rural Development, 25(10).

[3] Buecher, S. (1995). Encourager le progrès économique des femmes . UNIFEM News.

[4] Caro, D., Pangare, V., \& Manfre, C. (2013). Gender impact assessment of the ASI Sunhara India Project. Retrieved from Cultural Practice. Retrieved from www.culturalpractice.com/resources/gender-impactassessment-of-the-asi-sunhara-india-project/.

[5] De Hoop, T. v. (2014). Women's autonomy and subjective well- being: How gender norms shape the impact of self- help groups in Odisha, India. Feminist Economics, 20(3), 103-135.

[6] Desai, R. M., \& Joshi, S. (2013). Collective action and community development: Evidence from self-help groups in rural India. Policy Research Working Paper No. WPS 6547.

[7] DGESS. (2019). Annuaires statistiques. Ouagadougou: Ministere de la Jeunesse et de la Promotion de l'Entrepreneuriat des Jeunes.

[8] Dumouchel, S., \& Nancy Thede, N. (1985). Femmes, épargne et crédit au sahel : les bases pour autodéveloppement, . Montréal.

[9] Duvendack, M., \& Mader, P. (2019). Impact of financial inclusion in low- and middle-income countries: A systematic review of reviews. London: 3ie Systematic Review 42.

[10] Greaney, B., Kaboski, J. P., \& Van Leemput, E. (2013). Can Self-Help Groups really be "self-help"? NBER Working Papers No. 18970, National Bureau of Economic Research.

[11] Gugerty, M. K., Biscaye, P., \& Anderson, C. L. (2019). Delivering development? Evidence on self- help groups as development intermediaries in South Asia and Africa. Development Policy Review, 129-151.

[12] Haque, M., \& Itohara, Y. (2009). Women's empowerment through participation in micro-credit programme: A case study from Bangladesh. Journal of Social Science, 5(3), 244-250.

[13] Hargreaves, J., Hatcher, A., Strange, V., Phetla, G., Busza, J., Kim, J., \& Bonell, C. (2009). Process evaluation of the Intervention with Microfinance for AIDS and Gender Equity (IMAGE) in rural South Africa. Health Education Research, 27-40.

[14] Hashemi, S. M., \& Schuler, S. R. (1996). Rural Credit Programs and Women's Empowerment in Bangladesh. World Development, 24(4), 635-653.

[15] Holvoet, N. (2005). The impact of microfinance on decision- making agency: Evidence from South India. Development and Change, 75-102.

[16] Jefferis, K., \& Abdulai, J. (2017). Making Access Possible. Ouagadougou: MEF.

[17] Khandker, S. R. (2005). Microfinance and Poverty: Evidence Using Panel: Data from Bangladesh. THE WORLD BANK ECONOMIC REVIEW, 19(2), 263286.
[18] Lassi, Z. S., Haider, B. A., \& Bhutta, Z. A. (2010). . (2010). Community- based intervention packages for reducing maternal and neonatal morbidity and mortality and improving neonatal outcomes. Cochrane Database of Systematic Reviews.

[19] Lassi, Z. S., Kumar, R., \& Bhutta, Z. A. (2016). Community-based care to improve maternal, newborn, and child health. Reproductive, maternal, newborn and child health , 263-284.

[20] Mahtab, N. (2007). Women in Bangladesh, from inequality to empowerment. Dhaka: A H Development Publishing House.

[21] Mercer, C. (2002). The disclosure of Maendeleo and the politics of women's participation on Mount Kilimanjaro . Development and Change, 101-27.

[22] Mukherjee, A., \& Kundu, A. (2012). Microcredit and women's agency: a comparative perspective across socioreligious communities in West Bengal India. Gender, Technology and Development, 16(1), 71-94.

[23] N'DA, P. (2006). Méthodologie de la recherche de la problématique à la discussion des résultats. Abidjan: Éditions universitaire de Cocody.

[24] Nawaz, N., Jahanian, A., \& Manzoor, S. W. (2012). Empowering women through microcredit: A case study of Tameer microfinance bank, Bahawalpur. Journal of Economics and Sustainable Development, 3(2), 17-21.

[25] Nessa, T., Ali, J., \& Abdul-Hakim, R. (2012). The impact of microcredit programme on women's empowerment: evidence from Bangladesh. OIDA International Journal of Sustainable Development, 3(9), 11-20.

[26] Odell, M. (2012). Micro-finance in Africa: State-of-theSector Report 2011. Closing the gap. Retrieved from the CARE. Retrieved from https://www.care.org/sites/default/files/documents/MF2011-CARE-Access-Africa-Closing-the-Gap.pdf.

[27] Odell, M., \& Rippey, P. (2011). Beyond financial services: The permanence and value of savings groups in CARE Kenya's COSAMO Programme. Retrieved from https://www.mangotree.org/Resource/.

[28] Pitt, M. M., \& Khandker, S. R. (1996). Household and Intrahousehold Impact of the Grameen Bank and Similar Targeted Credit Programs in Bangladesh. Washington, D.C: Discussion Paper 320. World Bank.

[29] Rogers, P. (2014). Theory of Change, Methodological Briefs-Impact Evaluation. Florence: Bureau de recherches de l'UNICEF.

[30] Rosenberg, M., Seavey, B. K., Jules, R., \& Kershaw, T. (2011). The role of a microfinance programme on HIV risk behaviour among Haitian women. AIDS and Behavior, 911-18.

[31] Sarkar, A. R. (2000). Women in microcredit and their empowerment-Case study of BRAC societies under Sherpur Upazila of Bogra District. Bogra: Tajma Art Press.

[32] Sherman, S. G., Srikrishnan, A. K., Rivett, K. A., Liu, S., Solomon, S., \& Celentano, D. (2010). Acceptability of a microenterprise intervention among female sex workers in Chennai, India. AIDS and Behavior, 649-657.

[33] Steele, F., Amid, S., \& Naved, R. T. (1998). The impact of an integrated micro-credit program on women's empowerment and fertility behaviour in rural 
Bangladesh. $\quad$ Retrieved from

http://www.popcouncil.org/uploads/pdfs/wp/115.pdf.
[34] Voica: M, C. (2017). Financial Inclusion as a Tool for Sustainable Development. . Retrieved from http://www.researchgate.net/publication/320710010. 